\title{
Albania: Report on Observance of Standards and Codes-FATF Recommendations for Anti-Money Laundering and Combating the Financing of Terrorism
}

This Report on the Observance of Standards and Codes on the FATF Recommendations for AntiMoney Laundering and Combating the Financing of Terrorism for Albania was prepared by a team of the International Monetary Fund using the assessment methodology adopted by the Financial Action Task Force in February 2004 and endorsed by the Executive Board of the IMF in March 2004. The views expressed in this document, as well as in the full assessment report, are those of the IMF team and do not necessarily reflect the views of the Government of Albania or the Executive Board of the IMF.

Copies of this report are available to the public from

International Monetary Fund $\bullet$ Publication Services 700 19th Street, N.W. • Washington, D.C. 20431

Telephone: (202) 6237430 • Telefax: (202) 6237201

E-mail: publications@imf.org • Internet: http://www.imf.org

\section{International Monetary Fund Washington, D.C.}




\section{INTERNATIONAL MONETARY FUND}

\section{REPUBLIC OF ALBANIA}

\section{Report on Observance of Standards and Codes (ROSC)—FATF Recommendations for}

Anti-Money Laundering and Combating the Financing of Terrorism (AML/CFT)

Prepared by the Legal Department

Approved by Sean Hagan 


\section{ABBREVIATIONS}

$\begin{array}{ll}\text { AML/CFT } & \text { Anti-Money Laundering and Combating the Financing of Terrorism } \\ \text { BCP } & \text { Basel Core Principles } \\ \text { BoA } & \text { Bank of Albania } \\ \text { BL } & \text { Banking Law } \\ \text { CC } & \text { Criminal Code } \\ \text { CDD } & \text { Customer Due Diligence } \\ \text { CPC } & \text { Criminal Procedure Code } \\ \text { CSP } & \text { Company Service Provider } \\ \text { DAR } & \text { Detailed Assessment Report } \\ \text { DNFBP } & \text { Designated Nonfinancial Businesses and Professions } \\ \text { FATF } & \text { Financial Action Task Force } \\ \text { FI } & \text { Financial Institution } \\ \text { FIU } & \text { Financial Intelligence Unit } \\ \text { FSA } & \text { Financial Supervisory Authority } \\ \text { FSAP } & \text { Financial Sector Assessment Program } \\ \text { FSRB } & \text { FATF-style Regional Body } \\ \text { FT } & \text { Financing of Terrorism } \\ \text { GDPML } & \text { General Directorate for the Prevention of Money Laudering } \\ \text { IAIS } & \text { International Association of Insurance Supervisors } \\ \text { JIU } & \text { Joint Investigation Unit } \\ \text { KYC } & \text { Know your customer/client } \\ \text { LEG } & \text { Legal Department of the IMF } \\ \text { MEF } & \text { Ministry of Economy and Finance } \\ \text { MFA } & \text { Ministry of Foreign Affairs } \\ \text { MOU } & \text { Memorandum of Understanding } \\ \text { ML } & \text { Money Laundering } \\ \text { MLA } & \text { Mutual Legal Assistance } \\ \text { NPO } & \text { Nonprofit organization } \\ \text { NRC } & \text { National Registration Center } \\ \text { OEM } & \text { Other Enforceable Means } \\ \text { PEP } & \text { Politically-Exposed Person } \\ \text { ROSC } & \text { Report on Observance of Standards and Codes } \\ \text { SAR } & \text { Suspicious Activity Report } \\ \text { SRO } & \text { Self-regulatory Organization } \\ \text { STR } & \text { Suspicious Transaction Report } \\ \text { SUGC } & \text { Supervision Unit of the Games of Chance } \\ \text { UN } & \text { United Nations Organization } \\ \text { UNSCR } & \text { United Nations Security Council Resolution } \\ & \end{array}$




\section{A. Introduction}

This Report on the Observance of Standards and Codes for the FATF 40 Recommendations for AntiMoney Laundering (AML) and 9 Special Recommendations on Combating the Financing of Terrorism (CFT) was prepared by the IMF. ${ }^{1}$ The report provides a summary of the AML/CFT measures in place in Albania and of the level of compliance with the FATF 40+9 Recommendations, and contains recommendations on how the AML/CFT system could be strengthened. The assessment is based on the information available at the time of the mission from November 15-30, 2010 and other verifiable information subsequently provided by the authorities. It was conducted using the 2004 Methodology as updated. The Detailed Assessment Report (DAR) on which this document is based was adopted by the MONEYVAL plenary on April 13, 2011. The views expressed here, as well as in the full assessment report, are those of the staff team, and do not necessarily reflect the views of the Government of Albania or the Executive Board of the IMF.

\section{B. Key Findings of the Assessment}

1. Although Albania has made considerable progress to tackle ML and FT the risk of ML remains high. Albania has a history of organized crime with clan-based and hierarchically organized networks that are mainly involved in drug trafficking. The relative size of the cash-based informal economy facilitates the laundering and integration of proceeds of crime. The number of sectors identified with illegal practices, including illegal gambling establishments and exchange bureaus, as well as the vulnerabilities that relate to cross-border transportation of currency, also make Albania at risk for ML activity.

2. Despite efforts by the authorities to reduce the reliance on cash, the use of cash through the informal economy remains a problem in Albania. The use of the informal economy has an impact on the overall effectiveness of preventive measures as transactions facilitated through these channels circumvent the preventive measures established by the authorities.

3. Albania also remains at risk regarding possible financing of terrorism activities. There is a record in the first half of the 2000s of the government freezing assets of terrorist financiers, curtailing activities of suspect Islamic NPOs, and expelling individuals suspected of having links to terrorism.

4. Albania has fully criminalized ML largely in line with the requirements under the Vienna and Palermo Conventions. However, there have been few convictions for ML and demanding evidentiary requirements have had a negative impact upon Albania's ability to make effective use of the provisions. Also, the Albanian provisions that criminalize the financing of terrorism, although significantly enhanced in recent years, still fall short of meeting the FATF standard.

5. The Albanian FIU has improved its analytical processes resulting in higher quality financial intelligence; however the legal framework needs to be strengthened with regard to its operational independence. The FIU's responsibility to disseminate information regarding suspicious transactions should also be clarified.

6. Albania has updated the legal framework for preventive measures for financial institutions, but the requirements fall short of the international standard in some areas, such as for the identification of beneficial owners, and the lack of any customer due diligence (CDD) measures for

\footnotetext{
${ }^{1}$ The assessment team consisted of Giuseppe Lombardo (team leader), Marilyne Landry, and Rocio Ortiz Escario (all of LEG); Margaret Cotter and Ian Matthews (consultants).
} 
customers that are foreign politically exposed persons (PEPs). In addition, the effectiveness of implementation of preventive measures remains a concern, with uneven understanding of the provisions amongst financial institutions and a lack of suspicious transaction reports.

7. Implementation of preventive measures by designated non-financial businesses and professions (DNFBPs) is limited. A large range of DNFBPs have been subject to supervision by the FIU however other designated supervisors have had limited engagement in AML/CFT activities.

8. The legal framework underpinning the supervisory authorities' power is sound but the supervisory role of the FIU should be clarified. Moreover, the Financial Supervisory Authority (FSA) has not undertaken any inspection of the securities and insurance sectors.

9. Domestic and international cooperation is good. Albania has established a number of domestic and international cooperation mechanisms that facilitate cooperation between competent authorities and foreign counterparts; however, cooperation mechanisms between supervisory agencies, both domestically and internationally, are underutilized.

\section{Legal Systems and Related Institutional Measures}

10. Albania has fully criminalized ML largely in line with the requirements under the Vienna and Palermo Conventions. The Albanian ML provisions extend to any type of property as defined in the FATF standard and also apply in most instances to persons who commit the predicate offense. The provisions do not, however, extend to the FATF-designated predicate offenses of insider trading and market manipulation. Most appropriate ancillary offenses are provided for. There have been few convictions for ML and demanding evidentiary requirements have impacted Albania's ability to make effective use of the provisions.

11. Albania has provisions criminalizing both collection for, and the financing of, terrorism. Its legal framework also provides a specific definition of actions with terrorist purposes that are then prohibited. These provisions represent significant progress since the 2006 assessment but still fall short of meeting the requirements under the FATF Recommendations and the U.N. Financing of Terrorism Convention (FT Convention). Among the shortcomings are that it is not clear that provision and collection are prohibited in the absence of the commission or attempted commission of a terrorist act; there is a specific purpose or intent requirement applied in the case of conducts covered by the offenses set forth in the nine Conventions and Protocols listed in the Annex to the FT Convention; the criminal provisions do not sufficiently apply to the financing of all of the conducts set forth in the offenses in such annexed Conventions; financing does not clearly extend to the full extent of "funds" as defined in the FT Convention; and the financing of an individual terrorist is criminalized only if the funds are provided or collected to support terrorist activities.

12. Albania has in place a comprehensive legal framework to seize and confiscate the proceeds of crime. In addition to provisions that permit seizure and confiscation in criminal cases, the new Organized Crime Law adopted in late 2009 provides for preventive seizure and confiscation using a civil standard for a wide range of serious offences. However, as yet there have been few actual confiscations and limited use of sequester authority in ML cases. Criminal Code provisions have thus far not been used effectively to produce results. The provisions of the 2009 Organized Crime Law are just beginning to be applied in case settings and provide promise for positive results going forward.

13. Albania has a sound legal foundation to implement its obligations under UN Security Council Resolution 1267 but the legal provisions that apply in the case of UNSCR 1373 are uncertain. The framework has been effectively applied to freeze the funds and assets of designated terrorists and terrorist organizations. However, supervision for compliance is lacking in practice and the required legal 
framework is insufficient. A number of significant technical deficiencies were also identified, including insufficient updating of the domestic list that sets forth the names of persons whose assets must be frozen; the absence of secondary provisions to address requests by affected persons for subsistence or other expenditures; and the lack of guidance to the private sector and publically-available information on delisting and unfreezing procedures.

14. Albania's financial intelligence unit (FIU) is seen by law enforcement and intelligence agencies as producing timely and high quality financial intelligence. The FIU has aligned its activities with activities of the Joint Investigation Units (JIUs) resulting in disseminations of its financial intelligence being integrated in a greater number of investigations. The timeliness of disseminations has improved and dissemination packages are considered more comprehensive due to the addition of cash reporting requirements and the lowering of thresholds. The effectiveness of its analytical activities could be enhanced by conducting more trend analysis and establishing a prioritization mechanism for STRs and other transaction reports. Concerns remain about the independence of the FIU due to the absence of statutory independence of the Directorate. The FIU's responsibility to disseminate disclosures of suspicious transactions to domestic authorities should be made more explicit.

15. The creation of JIUs has enhanced collaboration between domestic AML/CFT stakeholders and resulted in an increase in the number of money laundering investigations. The establishment of the JIUs has resulted in increased efficiency of ML investigations with the number of investigations having doubled from 2008 to 2009. However, challenges persist in establishing arrests and prosecutions. Amendments to the legislative framework are needed to explicitly provide law enforcement authorities with the ability to postpone and waive arrest warrants and allow them to conduct interceptions without advising defense counsel. The judiciary lacks the expertise to review complex money laundering cases and requires training. Concerns have also been expressed about the integrity of the judiciary. ${ }^{2}$

16. There has been significant progress in the area of oversight of cross-border transportation of currency, but the number of declarations remains low. Cash couriers need to be tackled more effectively. Customs' capacity to collect and analyze data related to cross-border transportation of currency should be strengthened.

\section{Preventive Measures-Financial Institutions}

17. Albania has improved the legal framework concerning AML/CFT preventive measures. The AML/CFT Law, adopted in 2008, establishes requirements for CDD, correspondent banking, unusual transactions, record keeping and the reporting of suspicious transactions. The AML/CFT Law covers all financial activities covered by the FATF definition of "financial institutions".

18. The legal framework for CDD covers, to an extent, the required essential criteria, but there are a number of technical gaps. In particular, some of the provisions technically only apply to the identification and verification of customers and not to other components of CDD, the requirements for identifying and verifying the identity of beneficial owners are incomplete and inconsistent, and there are limited provisions for carrying out CDD where there is a suspicion of money laundering and terrorist financing. The measures required for conducting enhanced due diligence are also inconsistently implemented by financial institutions, and there are very limited requirements for ongoing due diligence. The requirements for establishing correspondent banking relationships have been improved. There are still no requirements regarding foreign PEPs.

\footnotetext{
${ }^{2}$ European Commission, Commission Opinion on Albania's application for membership of the European Union.
} 
19. Implementation of preventive measures remains uneven across the financial sector. The banking sector demonstrated the best understanding of the measures, and was sometimes complying to a standard in excess of that required by law. However, this tended to be as a result of higher overseas group standards. Measures for ongoing monitoring and for identifying and verifying beneficial ownership were poorly implemented, with some confusion amongst financial institutions as to the scope of the requirements. In addition, whilst the concept of customer risk factors is a new development in the Albanian system which is to be encouraged, its effectiveness would be enhanced with additional guidance on how to use them.

20. The legal requirements for submitting suspicious transaction reports have been improved. However, there remain some technical deficiencies, and the number of reports in comparison to the higher number of currency transaction reports gives rise to concerns about effectiveness. In particular, the shortcomings noted with regard to the criminalization of money laundering and terrorist financing limit the circumstances in which reports are required. There is no specific requirement to report attempted transactions, and Albania has a number of exemptions from the requirement to report suspicious transactions which are not in line with the FATF standards. The very low number of terrorist financing reports also raises concerns about the effectiveness of the provisions, especially in the light of the risk that Albania faces in relation to the financing of terrorism via NPOs.

21. Although there are measures in Albania to prevent criminals from owning or controlling financial entities there remain activities carried out by non-licensed operators. This is the case with informal bureaus of foreign exchange and money transmitters, which are operating outside the regulated market and constitute a risk for ML and TF activities.

22. The financial supervisors - the Bank of Albania (BoA) for banks and other financial institutions and the Financial Supervisory Authority (FSA) for insurance and securities - have adequate powers to ensure FIs compliance with their AML/CFT obligations but the supervisory approach and implementation is uneven across the financial sector. BoA offsite monitoring is inadequate and the onsite risk-based supervision is at an embryonic stage of implementation. The FSA has not been supervising the securities and insurance sectors for AML/CFT compliance.

23. The FIU also has supervisory responsibilities with regard to the reporting obligations. However the inspections carried out by the FIU seem to cover a broader range of requirements than provided by the law. The FIU has been the only supervisor that has actually imposed sanctions to reporting entities for non-compliance with the AML/CFT requirements.

\section{E. Preventive Measures-Designated Nonfinancial Businesses and Professions}

24. The preventive measures for DNFBPs mirror those for financial institutions; however their implementation is at an early stage. Preventive measures apply to all DNFBP categories (with the exception of some trust and company service provider activities). Some customer identification and record keeping obligations are being met but the majority of obligations are not complied with due to lack of knowledge and the absence of guidance. Authorities should address more proactively illegal gambling operations in order to mitigate the money laundering risk.

25. The designation of supervisory authorities for DNFBPs needs to be clarified. A number of supervisory authorities have been designated as AML/CFT supervisors in their respective areas of responsibility. However, very few AML/CFT examinations have been conducted by these authorities and their understanding of ML/FT vulnerabilities is limited. The FIU is undertaking supervisory activities in all DNFBP sectors despite the absence of clear legislative authority to ensure compliance with non- 
reporting requirements. The supervisory responsibilities of the FIU as well as of the other supervisors need to be clearly delineated and respected.

\section{F. Legal Persons and Arrangements and Non-Profit Organizations}

26. Albania has improved the legal framework concerning legal persons and the authorities' access to beneficial ownership information. The establishment of the National Registration Center (NRC) constitutes a positive step towards ensuring more transparency of legal persons. However, Albanian authorities have not taken measures to ensure that bearer shares are not misused for ML purposes.

27. The measures in place in Albania relating to NPOs are deficient. No formal review of the sector has been carried out, and there is no formal supervision of the sector. Unlike the case of for-profit companies the legal framework concerning NPOs has not been updated and is flawed, in that it does not provide accurate information on beneficial ownership. The registration requirements are largely quantitative, with few checks on the information provided. There is also a lack of outreach to the NPO sector. Albania has demonstrated that it is aware that NPOs pose a TF risk, as financial institutions are required to conduct enhanced CDD in relation to them.

\section{G. National and International Cooperation}

28. The establishment of the inter-agency Coordination Committee against Money Laundering and the development of a National Strategy on the Investigation of Financial Crimes provide a good basis for domestic collaboration. The Coordination Committee and its associated working group provide for a for discussing the implementation of the National Strategy as well as operational issues. The creation of the JIUs has also contributed to greater collaboration between law enforcement, intelligence agencies, the prosecutor's office, the FIU as well as other government agencies responsible for the fight against money laundering. However, cooperation between supervisory agencies should be improved and the FIU should work more closely with the financial supervisors to coordinate inspections and share findings. Statistics gathering is not coordinated resulting in inconsistencies in the data.

29. International cooperation mechanisms are in place for the FIU, law enforcement agencies and certain supervisors. Information exchanged with foreign FIUs is comprehensive and timely. Despite mechanisms being in place through Interpol, there is no evidence of collaboration between law enforcement agencies outside MLAT channels. Financial sector supervisors have memoranda of understanding in place to exchange information with their foreign counterparts; however these mechanisms do not appear to be frequently utilized.

30. Albania cooperates internationally based on the provisions of the Criminal Procedure Code (CPC) and the recently enacted 2009 Mutual Legal Assistance Law. The latter supplements the CPC provisions and will provide an enhanced legal framework for assistance going forward. The authorities may provide a wide range of assistance in relation to ML and FT cases. The granting of such assistance is not subject to any unduly restrictive or unreasonable conditions. In cases where dual criminality is required, the shortcomings identified in relation to the provisions criminalizing ML and FT may limit the authorities' ability to provide MLA. For assistance in confiscating assets, there is a limited ability under the current legal framework to execute foreign requests. There are a few practical barriers in the provision of assistance such as the application of principles of dual criminality in all circumstances, the necessity of a court order for every execution and occasional use of diplomatic channels.

31. ML is an extraditable offense in relation to Council of Europe Member States and countries with which the Albania has entered into a bilateral or multilateral extradition treaty. Albania may 
also extradite even without a treaty based upon reciprocity. FT is an extraditable offense but based on the dual criminality requirement, the shortcomings identified under Special Recommendation II may limit the Albanian ability to extradite in certain FT cases. A CPC provision that provides the Minister of Justice with wide discretion to impose requirements on extradition should be reviewed because of its potential to be used to defeat extradition. 
Summary Table of Observance and Key Recommendations

\begin{tabular}{|c|c|}
\hline FATF 40+9 Recommendations ${ }^{3}$ & Key Assessor Recommendations \\
\hline \multicolumn{2}{|r|}{ 1. Legal System and Related Institutional Measures } \\
\hline $\begin{array}{l}\text { Criminalization of Money Laundering } \\
\text { R.1 - PC } \\
\text { R. } 2 \text { - LC }\end{array}$ & $\begin{array}{l}\text { - Enact a provision or amend existing provisions so that self-laundering is covered for } \\
\text { the Article } 287 / \mathrm{b} \text { offences; } \\
\text { - Extend criminalization of use beyond the use and investment in economic or } \\
\text { financial activities; } \\
\text { - Amend Article } 287 / \mathrm{b} \text { so that it is clear that its coverage extends beyond acquisition, } \\
\text { possession or use in the case of stolen goods; } \\
\text { - Enact provisions to cover insider trading and market manipulation; } \\
\text { - Enact provisions so that all required ancillary activity is covered; } \\
\text { - Provide training for courts, prosecutors and judicial police that will permit better use } \\
\text { of existing provisions under more liberal standards; } \\
\text { - Utilize Article } 287 / \mathrm{b} \text { CC more pro-actively. }\end{array}$ \\
\hline $\begin{array}{l}\text { Criminalization of Terrorist Financing } \\
\text { SR.II - PC }\end{array}$ & $\begin{array}{l}\text { - Enact amendments to the FT criminalization provisions in Chapter VII of the CC } \\
\text { provisions, so that: } \\
\text { O Article 230/a applies regardless of whether the terrorist act is actually committed } \\
\text { or attempted and when there is only an intention that the funds be used; } \\
\text { it is clear that the financing prohibited extends to the full extent of "funds" as } \\
\text { that term is defined in the FT Convention; } \\
\text { the financing of individual terrorists regardless of whether the funds are provided } \\
\text { or collected to support terrorist activities is criminalized. } \\
\text { Enact amendments to Article } 230 \text { CC so that: } \\
\text { it covers each specific action that is required to be criminalized under all the } \\
\text { treaties that are annexed to the FT Convention; } \\
\text { it covers actions "intended to cause" death or serious bodily harm, not simply that } \\
\text { "might" cause this; } \\
\text { the specific purpose or intent requirement set forth in Article } 2 \text { para. } 1 \text { (b) of the } \\
\text { FT Convention is not required in the case of the conducts specified in the annexed } \\
\text { treaties (Article 2, para. 1(a)); } \\
\text { the purpose set forth in the Article is to compel the Albanian or foreign } \\
\text { government rather than "Albanian or foreign governmental agencies". }\end{array}$ \\
\hline $\begin{array}{l}\text { Confiscation, freezing, and seizing of } \\
\text { proceeds of crime } \\
\text { R. } 3 \text { - LC }\end{array}$ & $\begin{array}{l}\text { - Through enhanced CC or CPC legislative provisions and/or the better use of } \\
\text { existing provisions in criminal cases and/or parallel use of Organized Crime Act } \\
\text { civil proceedings, work towards developing a framework that is effective in actually } \\
\text { recovering criminal assets without the same degree of tracing, specificity and } \\
\text { linkage between specific criminal acts and specific monies. } \\
\text { - Make fuller use of the provisions in part by emphasizing the importance to law } \\
\text { enforcement and prosecutors that criminal assets be pursued early on in every } \\
\text { proceeds-generating crime under investigation/prosecution. } \\
\text { - Establish a national registry of bank accounts administered by the BoA, which, upon } \\
\text { proper authority, can be accessed on request by Law Enforcement authorities' } \\
\text { powers to facilitate the investigation of ML/FT, in order to enhance their capacity to } \\
\text { identify and trace property that is or may become subject to confiscation or is } \\
\text { suspected of being the proceeds of crime. } \\
\text { - Include corruption as an offence under the Organized Crime Law which provides a }\end{array}$ \\
\hline
\end{tabular}

\footnotetext{
${ }^{3}$ Compliant (C): the Recommendation is fully observed with respect to all essential criteria. Largely compliant (LC): there are only minor shortcomings, with a large majority of the essential criteria being fully met. Partially compliant (PC): the country has taken some substantive action and complies with some of the essential criteria. Non-compliant (NC): there are major shortcomings, with a large majority of the essential criteria not being met. Not applicable (NA): a requirement or part of a requirement does not apply, due to the structural, legal or institutional features of a country.
} 


\begin{tabular}{|c|c|}
\hline & $\begin{array}{l}\text { civil standard and reverse onus in the recovery of proceeds of crime. } \\
\text { Provide training to the judiciary and prosecutors so they have a greater } \\
\text { understanding of how provisions similar to the existing CC and CPC provisions for } \\
\text { criminal confiscation in other civil law contexts are applied in a more lenient and } \\
\text { effective fashion. } \\
\text { - Make fuller use of the provisions in part by emphasizing the importance to law } \\
\text { enforcement and prosecutors that criminal assets be pursued early on in every } \\
\text { proceeds-generating crime under investigation/prosecution. }\end{array}$ \\
\hline $\begin{array}{l}\text { Freezing of funds used for terrorist } \\
\text { financing } \\
\text { SR.III - PC }\end{array}$ & $\begin{array}{l}\text { - Revise the SFT Law to provide a clear legal basis for the Council of Ministers to } \\
\text { make a designation pursuant to UNSCR } 1373 \text {. } \\
\text { - Enact a provision that gives persons listed in the UNSCR } 1373 \text { context a right to } \\
\text { challenge not only a freeze but their listing (on grounds in addition to mistaken } \\
\text { identity). } \\
\text { - Adopt secondary provisions or mechanisms to address potential requests by affected } \\
\text { persons for subsistence or other expenditures. } \\
\text { - Continuously update the Council of Minister's domestic list or provide a legal } \\
\text { mechanism for automatic incorporation of the UNSCR } 1267 \text { list. } \\
\text { - Provide guidance to the private sector and the public at large about their obligations. } \\
\text { - Provide a legal mandate for the review of the compliance by entities subject to the } \\
\text { AML/CFT Law with their obligations regarding the Council of Ministers list and } \\
\text { regarding freezing of funds. } \\
\text { - Consider on a regular basis whether there are persons/entities that should be } \\
\text { designated domestically under UNSCR } 1373 \text { and make such designations. } \\
\text { - Undertake more vigorous supervisory review of institutions for compliance with } \\
\text { UNSCR obligations and include material in supervisory inspection } \\
\text { manual/checklists. }\end{array}$ \\
\hline $\begin{array}{l}\text { The Financial Intelligence Unit and } \\
\text { its functions } \\
\text { R. } 26-\text { LC }\end{array}$ & $\begin{array}{l}\text { - Expand the GDPML's authority to request additional information by specifically } \\
\text { allowing it to request non-financial information that could assist in its functions. } \\
\text { - Amend the Council of Minister's Decision outlining the organization and } \\
\text { functioning of the GDPML to reflect the FIU's new responsibilities. } \\
\text { - Clarify the GDPML's authority to exchange information with non law enforcement } \\
\text { authorities. } \\
\text { - Enhance the GDPML's strategic analytical capacity by conducting an in-depth } \\
\text { review of existing disseminations to identify ML/FT trends specific to Albania. } \\
\text { This information should be disseminated to help inform risk assessment activities by } \\
\text { both authorities and obliged entities. } \\
\text { - Enhance the IT system so that it allows for the prioritization of STRs and identifies } \\
\text { patterns of suspicious transactions generating cases based on these findings. } \\
\text { - Specify the autonomy and independence of the GDPML in legislation and establish } \\
\text { a fixed term for the General Director and include a provision on the independent } \\
\text { status of the Director. }\end{array}$ \\
\hline $\begin{array}{l}\text { Law enforcement, prosecution and } \\
\text { other competent authorities } \\
\text { R. } 27-\text { PC } \\
\text { R. } 28-\text { C }\end{array}$ & $\begin{array}{l}\text { - Conduct targeted training to the judiciary to increase their knowledge of ML, its } \\
\text { inherent complexities and proceeds of crime in general. } \\
\text { - Amend the provisions related to interception to remove the requirement to advise } \\
\text { defense counsel that an interception activity has occurred five day following the } \\
\text { activity. }\end{array}$ \\
\hline $\begin{array}{l}\text { Cross Border Declaration or } \\
\text { disclosure } \\
\text { SR IX-PC }\end{array}$ & $\begin{array}{l}\text { - Define the notion of "negotiable instruments", so that it is fully consistent with the } \\
\text { FATF definition of "bearer negotiable instruments", and harmonize Article 187a of } \\
\text { the Criminal Code so that a proper reference to bearer negotiable instruments is } \\
\text { included. } \\
\text { - Improve Customs officers' access to information by: } \\
\text { - Providing Customs access to TIMS; } \\
\text { - Requiring the BMP to provide Customs all information related to the } \\
\text { declaration requirements; } \\
\text { - Interconnecting the databases at the Customs point and the database at the } \\
\text { Customs HQ Unit for the Prevention of ML, so that they can be mutually } \\
\text { queried. } \\
\text { - Amend the Criminal Code or the AML/CFT law to include sanctions for the case of } \\
\text { false/inaccurate declaration. }\end{array}$ \\
\hline
\end{tabular}




\begin{tabular}{|c|c|}
\hline & $\begin{array}{l}\text { - Require that cash deposits that are purported to be remittances from abroad are } \\
\text { accompanied by the Customs declaration, when they exceed the threshold. }\end{array}$ \\
\hline \multicolumn{2}{|c|}{ 2. Preventive Measures: Financial Institutions } \\
\hline \multicolumn{2}{|c|}{\begin{tabular}{l|l} 
Risk of money laundering or terrorist & \\
financing
\end{tabular}} \\
\hline $\begin{array}{l}\text { Customer due diligence, including } \\
\text { enhanced or reduced measures } \\
\text { R. } 5-\text { PC } \\
\text { R. } 6-\text { NC } \\
\text { R. } 7-\text { LC } \\
\text { R. } 8-\text { PC }\end{array}$ & $\begin{array}{l}\text { - Amend Articles } 1025 \text { and } 1026 \text { of the Civil Code and/or pass legislation to prohibit } \\
\text { the issuing of bearer passbooks and pass legislation to prohibit the issuing of any } \\
\text { other bearer instruments (e.g. certificates of deposit); } \\
\text { - Extend the circumstances when "CDD" is required to all aspects of CDD, not just } \\
\text { identification and verification; } \\
\text { - Clarify in law or regulation the requirement to verify that a person acting on behalf } \\
\text { of another is so authorized; } \\
\text { - Include a requirement in law or regulation to verify the identity of a beneficial } \\
\text { owner; } \\
\text { - Extend the requirements in relation to beneficial ownership to include beneficial } \\
\text { ownership of legal arrangements; } \\
\text { - Clarify the inconsistency between the AML/CFT Law and Instruction } 12 \text { regarding } \\
\text { the threshold for identifying the shareholding and voting rights of legal persons in } \\
\text { determining beneficial ownership; } \\
\text { - Establish a requirement in law or regulation to determine whether a person is acting } \\
\text { on behalf of another; } \\
\text { - Include a requirement in law, regulation or OEM that obliged entities obtain } \\
\text { information on the purpose and intended nature of the business relationship; } \\
\text { - Clarify the requirements in the AML/CFT Law on carrying out "continuous } \\
\text { monitoring", and on "periodically" updating client data by either amending the Law } \\
\text { itself or issuing further guidance to ensure that ongoing monitoring is fully and } \\
\text { consistently implemented by the obliged entities; } \\
\text { - Clarify in law, regulation or OEM, or in guidance, the steps to be taken in when } \\
\text { obliged entities are required to apply enhanced due diligence; } \\
\text { - Extend the requirements relating to PEPs to foreign PEPs; } \\
\text { - Provide a clear requirement to obtain on source of wealth and source of funds of } \\
\text { PEPs; }\end{array}$ \\
\hline $\begin{array}{l}\text { Third parties and introduced business } \\
\text { R.9- NC }\end{array}$ & $\begin{array}{l}\text { - Consider the ML/TF risks in allowing third party reliance, and then decide whether } \\
\text { allowing third party reliance would be appropriate and feasible in Albania. }\end{array}$ \\
\hline \multicolumn{2}{|l|}{$\begin{array}{l}\text { Financial institution secrecy or } \\
\text { confidentiality } \\
\text { R. } 4-\text { C }\end{array}$} \\
\hline $\begin{array}{l}\text { Record keeping and wire transfer } \\
\text { rules } \\
\text { R.10-LC } \\
\text { SR.VII - PC }\end{array}$ & $\begin{array}{l}\text { - Amend the record keeping requirement for "account files and business } \\
\text { correspondence" in the AML/CFT Law so that the five year period is calculated } \\
\text { "following the termination of an account or business relations", as required by the } \\
\text { FATF standard. } \\
\text { - Remove the option of requesting missing wire transfer-related information from the } \\
\text { beneficiary of the transaction. }\end{array}$ \\
\hline $\begin{array}{l}\text { Monitoring of transactions and } \\
\text { relationships } \\
\text { R. } 11-\text { PC } \\
\text { R. } 21-\text { PC }\end{array}$ & $\begin{array}{l}\text { - Impose a specific requirement for FIs to pay special attention to all complex, } \\
\text { unusual large transactions and unusual patterns of transactions which have no } \\
\text { apparent economic or visible lawful purpose. } \\
\text { - Require obliged entities to record the findings of their examination of complex and } \\
\text { unusual transactions in law, regulation or OEM. } \\
\text { - Require obliged entities to examine and make written findings of business } \\
\text { relationships and transactions with persons in countries with poor AML/CFT } \\
\text { controls, if they have no apparent economic or visible lawful background. } \\
\text { - Specify the counter-measures to be taken in cases where an FI deals with a person in } \\
\text { or from such a country. }\end{array}$ \\
\hline $\begin{array}{l}\text { Suspicious transaction reports and } \\
\text { other reporting } \\
\text { R.13-PC }\end{array}$ & $\begin{array}{l}\text { - Ensure that the SAR requirement extends to all categories of offences required in } \\
\text { the FATF standards; } \\
\text { - Extend the definition of STR (Article } 12 \text { para } 2 \text { ) to include the proceeds of criminal }\end{array}$ \\
\hline
\end{tabular}




\begin{tabular}{|c|c|}
\hline $\begin{array}{l}\text { R.14- LC } \\
\text { R.19-C } \\
\text { R. } 25-\text { PC } \\
\text { SR.IV - PC }\end{array}$ & $\begin{array}{l}\text { activity; } \\
\text { - Set out an explicit requirement in law or regulation that attempted transactions } \\
\text { should be reported; } \\
\text { - Remove the exemptions in Article } 13 \text { of the AML/CFT Law that relate to SARs. } \\
\text { - Ensure that all instances of tax evasion are reported. } \\
\text { - Clarify the AML/CFT law so that the prohibition against tipping off explicitly } \\
\text { applies to directors and officers as well as employees. } \\
\text { - Ensure that the SAR requirement extends to all categories of TF offences required } \\
\text { in the FATF standards, and that it applies to situations beyond intended terrorist } \\
\text { financing. }\end{array}$ \\
\hline $\begin{array}{l}\text { Internal controls, compliance, audit } \\
\text { and foreign branches } \\
\text { R. } 15 \text { - PC } \\
\text { R. } 22-\text { LC }\end{array}$ & $\begin{array}{l}\text { - Specifically include FT among the responsibilities of the compliance officer. } \\
\text { - Require that compliance officer has timely access to the data he/she may need. } \\
\text { - Require FIs to establish an independent audit function. } \\
\text { - Ensure that FIs put in place screening procedures to follow high standards when } \\
\text { hiring employees } \\
\text { - Introduce a specific requirement to FIs adopt the highest AML/CFT in case of } \\
\text { branch subsidiaries or branches in foreign countries. } \\
\text { - Ensure that the Albanian AML/CFT standards are applied in a consistent way } \\
\text { among the Albanian FIs foreign branches as a part of a group policy. }\end{array}$ \\
\hline $\begin{array}{l}\text { Shell banks } \\
\text { R.18- PC }\end{array}$ & $\begin{array}{l}\text { - Amend the AML/CFT Law to specifically prohibit FIs from operating with shell } \\
\text { banks. }\end{array}$ \\
\hline $\begin{array}{l}\text { Supervisory and oversight system- } \\
\text { competent authorities and SROs } \\
\text { Role, functions, duties and powers } \\
\text { (including sanctions) } \\
\text { R. } 17 \text { - PC } \\
\text { R.23 - PC } \\
\text { R. } 25 \text { - PC } \\
\text { R.29 - PC }\end{array}$ & $\begin{array}{l}\text { - Review and update insurance and securities sector laws to take into account the } \\
\text { requirements of the AML/CFT Law. } \\
\text { - Ensure adequate and effective AML/CFT supervision of the insurance and securities } \\
\text { sector by the FSA. } \\
\text { - Enhance the channels of communication and information exchange between the } \\
\text { GDPML and the supervision authorities. In particular the GDPML should share in a } \\
\text { timely fashion the findings of the inspections it undertakes with the BoA and the } \\
\text { FSA. } \\
\text { - Review the existing process to impose sanctions in order to remove any repetition of } \\
\text { inspections and the possibility to sanction twice for the same violation. } \\
\text { - Introduce a unified administrative sanctions regime for ML/FT violations in order to } \\
\text { avoid possible "supervisory arbitrage". } \\
\text { - Ensure that all the Albanian financial activities are subjected to adequate AML/CFT } \\
\text { regulation and supervision. } \\
\text { - Increase the inspections carried out on natural and legal persons providing a money } \\
\text { or value transfer services and to a money and currency changing services. } \\
\text { - Improve the offsite surveillance and risk-based onsite supervision. } \\
\text { - Establish legal requirements for fit and proper tests for all the FIs that are subject to } \\
\text { the Core Principles. }\end{array}$ \\
\hline $\begin{array}{l}\text { Money value transfer services } \\
\text { SR.VI - PC }\end{array}$ & $\begin{array}{l}\text { - Impose a direct requirement for MVT service operators to maintain a current list of } \\
\text { agents; } \\
\text { - Take further steps to ensure that remittance activity takes place in the formal sector. }\end{array}$ \\
\hline \multicolumn{2}{|c|}{ 3.Preventive Measures: Non-Financial Businesses and Professions } \\
\hline $\begin{array}{l}\text { Customer due diligence and record- } \\
\text { keeping } \\
\text { R.12-PC }\end{array}$ & $\begin{array}{l}\text { - Extend requirements to all TCSP activities defined by the standard. } \\
\text { - Increase the number of sanctions applied to games of chance operating illegally. } \\
\text { - The ASP should identify dealers in precious metals and stones that are operating } \\
\text { illegally and apply available sanctions. } \\
\text { - Implement outreach programs and develop guidance to raise awareness of customer } \\
\text { due diligence measures in the DNFBP sectors. }\end{array}$ \\
\hline $\begin{array}{l}\text { Suspicious transaction reporting } \\
\text { R.16-PC }\end{array}$ & $\begin{array}{l}\text { - Implement training and guidance targeted to DNFBPs to enhance knowledge of } \\
\text { STR detection reporting and internal control obligations as well as requirements to } \\
\text { apply special attentions to transactions related to countries who insufficiently apply } \\
\text { FATF recommendations. }\end{array}$ \\
\hline $\begin{array}{l}\text { Regulation, supervision, monitoring, } \\
\text { and sanctions }\end{array}$ & $\begin{array}{l}\text { - Designate a supervisor for real estate, accountants, and dealers in precious metals } \\
\text { and stones (DPMS). }\end{array}$ \\
\hline
\end{tabular}




\begin{tabular}{|c|c|}
\hline $\begin{array}{l}\text { R. } 24-\mathrm{PC} \\
\text { R. } 25-\mathrm{PC}\end{array}$ & $\begin{array}{l}\text { - Require designated supervisory authorities to develop an action plan on how } \\
\text { AML/CFT supervision will be integrated into their existing activities as well as } \\
\text { undertake more AML/CFT inspections. } \\
\text { - Review the casino license revocation provisions to allow license revocation in } \\
\text { repeated instances of non-compliance with AML/CFT obligations. } \\
\text { - Strengthen measures to prevent criminals or their associates from holding a } \\
\text { controlling interest in casinos or games of chance and include the screening of key } \\
\text { individuals by the conducting of criminal background checks on all shareholders, } \\
\text { managers, and beneficial owners' family members and close associates. } \\
\text { - Clarify in the AML/CFT law the authority of the GDPML to conduct inspections } \\
\text { related to compliance to AML/CFT requirements other than non-reporting } \\
\text { requirements. }\end{array}$ \\
\hline $\begin{array}{l}\text { Other designated non-financial } \\
\text { businesses and professions } \\
\text { R. } 20-\text { PC }\end{array}$ & $\begin{array}{l}\text {-Enforcing the requirement requiring taxpayers, physical or legal commercial } \\
\text { persons, not to engage in cash transactions where the amount is in excess of lek } \\
300,000 \text {. } \\
\text {-Fully implementing the recommendations of the public-private project-working } \\
\text { group on the Reduction of Cash Transactions in Albania. } \\
\text { - Requiring that all notarized transactions be conducted through a notary's trust } \\
\text { account. }\end{array}$ \\
\hline \multicolumn{2}{|c|}{ 4. Legal Persons and Arrangements \& Nonprofit Organizations } \\
\hline $\begin{array}{l}\text { Legal Persons-Access to beneficial } \\
\text { ownership and control information } \\
\text { R.33 - PC }\end{array}$ & $\begin{array}{l}\text { - Establish sanctions for the transitional regime-related obligations (commercial } \\
\text { companies); increase the existing sanctions so that they are dissuasive (commercial } \\
\text { companies); establish dissuasive sanctions for non compliance with the } \\
\text { requirements to provide information (associations and NPOs). } \\
\text { - Reform the system of registration of associations and NPOs, to ensure that } \\
\text { beneficial ownership and control information is adequate, accurate and current. } \\
\text { - Conduct a review of the information maintained by the Tirana District Court to } \\
\text { ensure that the files contain all the information required by the law and that this } \\
\text { information is accurate and up-to-date, especially for those associations/NPOs } \\
\text { established prior to } 2001 \text {. } \\
\text { - Conduct a risk assessment concerning bearer shares and take appropriate measures } \\
\text { to ensure that they are not misused for ML/FT (for example consider } \\
\text { "dematerializing" bearer shares). }\end{array}$ \\
\hline $\begin{array}{l}\text { Legal Arrangements-Access to } \\
\text { beneficial ownership and control } \\
\text { information } \\
\text { R.34-PC }\end{array}$ & Not applicable \\
\hline $\begin{array}{l}\text { Nonprofit organizations } \\
\text { SR.VIII - NC }\end{array}$ & $\begin{array}{l}\text { - Carry out a full risk assessment to establish what the TF risks are in the sector; } \\
\text { - Establish, on the basis of the above review, whether the current measures in place } \\
\text { for recording and accessing information relating to NPOs are proportionate to the } \\
\text { TF risks they pose; } \\
\text { - Improve the accuracy of the registration process for NPOs, including some form of } \\
\text { verification of the information recorded and a sanctionable system for failing to } \\
\text { update this information; } \\
\text { - Develop a system for supervising or monitoring NPOs on the basis of the risk they } \\
\text { present.. }\end{array}$ \\
\hline \multicolumn{2}{|c|}{ 5. National and International Cooperation } \\
\hline $\begin{array}{l}\text { National cooperation and } \\
\text { coordination } \\
\text { R. } 31-\text { LC }\end{array}$ & $\begin{array}{l}\text { - Conduct a review of the effectiveness of the AML/CFT system and conduct a } \\
\text { national risk assessment to inform the future strategies on the investigation of } \\
\text { financial crimes as well as provide guidance to obliged entities on the specific } \\
\text { AML/CFT vulnerabilities in place in Albania. } \\
\text { - Establish a forum between the GDPML and other designated AML/CFT supervisors } \\
\text { to engage functional supervisors, coordinate supervisory activities, exchange } \\
\text { inspection results, and ensure consistency in the application of AML/CFT } \\
\text { obligations. } \\
\text { - Include the GDPML and other supervisory bodies in the Committee to ensure that } \\
\text { supervisory concerns are properly reflected in the national strategy. }\end{array}$ \\
\hline $\begin{array}{l}\text { The Conventions and UN Special } \\
\text { Resolutions }\end{array}$ & $\begin{array}{l}\text { - Criminalize ML so that it is fully in line with the Vienna and Palermo Conventions.. } \\
\text { - Criminalize the FT so the offence is fully in line with FT Convention. }\end{array}$ \\
\hline
\end{tabular}




\begin{tabular}{|c|c|}
\hline $\begin{array}{l}\text { R.35 - PC } \\
\text { SR.I - PC }\end{array}$ & $\begin{array}{l}\text { - Address the shortcomings identified in relation to the implementation of } \\
\text { UNSCRs } 1267 \text { and } 1373 \text {. }\end{array}$ \\
\hline $\begin{array}{l}\text { Mutual Legal Assistance } \\
\text { R.36- LC } \\
\text { R.37- LC } \\
\text { R.38- PC } \\
\text { SR.V - PC }\end{array}$ & $\begin{array}{l}\text { - Enact provisions that will permit a broader ability to execute of foreign requests to } \\
\text { confiscate assets. } \\
\text { - Review existing domestic legal provisions that Albania uses to implement } \\
\text { obligations to provide assistance in identification, freezing, seizing and confiscation } \\
\text { pursuant to various international instruments to which Albania is a party, determine } \\
\text { their adequacy to meet all such obligations, and adopt provisions as necessary to } \\
\text { meet fully such obligations. } \\
\text { - Consider amending CPC Article } 509 \text { so that the diplomatic channel is no longer } \\
\text { required in the case of MLA requests that are executed using this provision. } \\
\text { - Undertake a review of possible barriers to more efficient provision of MLA } \\
\text { assistance including the application of dual criminality principles and the } \\
\text { requirement for use of diplomatic channels. } \\
\text { - Develop explicit procedures for urgent outgoing requests that ensure that such } \\
\text { requests are always identified and handled on an urgent basis. } \\
\text { - Through training, improve understanding by the judiciary and law enforcement of } \\
\text { the wider options available under international instruments with a view towards } \\
\text { addressing the tendency of the courts to apply strict interpretations and standards.. }\end{array}$ \\
\hline $\begin{array}{l}\text { Extradition } \\
\text { R.39- LC } \\
\text { R.37- LC } \\
\text { SR.V - PC }\end{array}$ & $\begin{array}{l}\text { - Amend the CPC (Article } 491 \text { para. } 3 \text { ) to delete the provision that appears to afford } \\
\text { the Minister of Justice too wide discretion with respect to extradition. } \\
\text { - Recognize, and as necessary perfect, competent authorities' ability to extradite } \\
\text { based upon the FT Convention (Article } 11 \text { ), Vienna (Article } 6 \text { para. } 3 \text { ) and Palermo } \\
\text { (Article } 16 \text { para. } 4 \text {-5) Conventions. Take steps necessary to deposit instruments } \\
\text { with the UN as necessary. } \\
\text { - Remedy the deficiencies in the FT and predicate offence for ML to ensure that dual } \\
\text { criminality does not limit extradition in such cases.. } \\
\text { - Decide whether there is an adequate legal basis to grant extradition in the absence of } \\
\text { a treaty based upon reciprocity and in what circumstances that can occur given CC } \\
\text { Article } 11 \text {, and make this clear to prosecutors and other relevant officials. }\end{array}$ \\
\hline $\begin{array}{l}\text { Other Forms of Cooperation } \\
\text { R. } 40 \text { - LC } \\
\text { SR.V - PC }\end{array}$ & $\begin{array}{l}\text { - Establish channels of cooperation with AML/CFT supervisors in the non-banking } \\
\text { sectors. } \\
\text { - Establish a clear authority for supervisory agencies to make inquiries or conduct } \\
\text { investigations on behalf of foreign counterparts. } \\
\text { - Establish safeguards to protect information received by foreign counterparts. }\end{array}$ \\
\hline \multicolumn{2}{|l|}{ 6. Other Issues } \\
\hline $\begin{array}{l}\text { Resources \& Statistics } \\
\text { R.30-PC } \\
\text { R.32-PC }\end{array}$ & $\begin{array}{l}\text { - Establish controls to reduce the occurrence of corruption within Customs and the } \\
\text { judiciary. } \\
\text { - Conduct targeted training to the judiciary to increase their knowledge of ML, its } \\
\text { inherent complexities and proceeds of crime in general. } \\
\text { - Provide training for courts, prosecutors and judicial police that instruct regarding } \\
\text { practices in Europe and elsewhere that will permit better use of existing provisions } \\
\text { under more liberal standards. } \\
\text { - Provide more training to customs officers in the area of AML/CFT, particularly with } \\
\text { regard to the detection of cash couriers. } \\
\text { - Implement AML/CFT training for individuals conducting AML/CFT supervision in } \\
\text { the, FSA, the Ministry of Justice, the Chamber of Advocates and the SUGC. } \\
\text { - Increase resources dedicated to AML/CFT within FSA, Customs and the SUGC. }\end{array}$ \\
\hline
\end{tabular}

